\title{
Effect of period of grouping of donors and duration of stimulus exposure on delay of puberty in female mice by a urinary chemosignal from grouped females
}

\author{
L. C. Drickamer \\ Biology Department, Williams College, Williamstown, Massachusetts 01267, U.S.A.
}

\begin{abstract}
Summary. Females housed at a density of $8 \mathrm{mice} / \mathrm{cage}$ had to be grouped for a minimum of about 10 days before their urine was capable of producing delays for first vaginal oestrus in test females comparable to the delays occasioned by treatment with urine from females grouped for 30 days or longer. Young test females had to receive a minimum daily exposure of $1-2 \mathrm{~h}$ to the chemosignal to produce the complete delay of puberty.
\end{abstract}

\section{Introduction}

Young female mice caged in groups or treated with urine from grouped females attain puberty later than females caged alone (Castro, 1967; Vandenbergh, Drickamer \& Colby, 1972; Drickamer, $1974,1982 a$ ). There is a general relationship between the density at which the mice are housed and the delay of maturation; mice caged at higher densities attain puberty later and their urine will also produce greater delays in puberty. The delay chemosignal is contained in the excreted urine of grouped, but not singly caged, females, and is present in the bladder urine of all females regardless of age or caging density (McIntosh \& Drickamer, 1977). The presence of the delay chemosignal in the urine is influenced by adrenalectomy (Drickamer \& McIntosh, 1980), but not by ovariectomy (Drickamer, McIntosh \& Rose, 1978). Singly caged females treated daily with urine from grouped females will produce the puberty-delaying chemosignal in their urine (Drickamer, 1982a).

Young female mice require at least 4 and possibly as many as 7 consecutive days of treatment with urine containing the delay chemosignal for puberty delay to occur (Drickamer, 1977). Treatment with the delay chemosignal is significantly more effective in retarding the age of puberty when urine application commences during the first week after weaning at 21 days of age (Drickamer, 1977). The present sequence of four experiments was designed to extend our knowledge of two aspects of the delay-of-maturation phenomenon-the length of time females must be grouped to initiate release of the delay chemosignal and the length of daily exposure to the chemosignal necessary to produce delays in puberty.

\section{General Methods}

All of the mice used in these experiments were from a randomly bred closed colony stock of ICR/Alb laboratory mice (Mus musculus). All colony and test mice were housed in cages of polypropylene measuring $15 \times 28 \times 15 \mathrm{~cm}$ with opaque sides and fitted wire lids. Colony and experimental rooms were maintained at $21-25^{\circ} \mathrm{C}$ and $30-60 \%$ relative humidity on a $12 \mathrm{~h}$ light $: 12 \mathrm{~h}$ dark lighting regimen with lights on from $06: 00 \mathrm{~h}$. Bedding of ground wood shavings was changed once per week. Wayne Lab-blox (Chicago, IL, U.S.A.) and water were always available. 
Pregnant female mice were placed in individual cages 1 week before parturition. All cages were then checked daily and births were recorded. On the day after birth the young in each litter were counted and sexed. Each litter was reduced to exactly 10 young to include at least 3 males. Litters of fewer than 10 young were discarded. Mice were weaned at 21 days after birth and were immediately assigned to a treatment according to a random sequence.

Each test mouse was examined daily from Day 21 until the occurrence of vaginal perforation. Starting on the day of vaginal perforation, a vaginal lavage was made each day until the occurrence of first vaginal oestrus. The vaginal smears were examined immediately with a microscope and judged to determine the stage of the oestrous cycle according to the criteria of Rugh (1968) and Vandenbergh (1969). Each mouse was weighed to the nearest $0 \cdot 1 \mathrm{~g}$ on Day 21 ; separate analyses of variance revealed no significant differences in the weaning weights for the various treatments in each experiment. The data for age of first oestrus for each experiment were subjected to a one-way analysis of variance.

\section{Detailed Methods and Results}

\section{Experiments $I$ and $I I$}

The effects of housing the donor females together for various lengths of time on the presence of the maturation-delaying chemosignal in the urine were tested.

Methods. For Exp. I, 75 female mice were weaned and assigned to a treatment group (15 mice/group); individually caged females were painted daily on the external nares with water (control; Group 1), or urine from females caged together for 1-3 days at the time of urine collection (Group 2), females caged together for 4-6 days (Group 3), 7-9 days (Group 4) or for at least 30 days (Group 5) before urine collection.

All group-caged urine donors were 90-150 days of age at the time of the experiment and were housed in groups of $8 \mathrm{mice} / \mathrm{cage}$. Before being caged in groups these donor females were housed individually for 20 days. Fresh urine was collected each day from 5-8 mice for each treatment. Urine was collected by holding the females over a Petri dish and gently rubbing the flanks. Urine was applied to the external nares of test females using 3-4 strokes of small paintbrush $(\sim 0.01 \mathrm{ml})$. Each test mouse was monitored as described in 'General Methods' until the occurrence of first vaginal oestrus.

The methods for Exp. II were identical to those of Exp. I except that the treatments for Groups 2 and 3 were replaced by daily painting with urine collected from females caged in groups of 8/cage for 10-12 or 13-15 days before being used as urine donors.

Results. For Exp. I the mice in Groups 1,2 and 3 all matured significantly earlier than did the mice in Group 5 (Table 1). Females in Group 4 were intermediate in age of first oestrus. In Exp. II the mice in Groups 2, 3 and 5 matured significantly later than did the control mice in Group 1 (Table 1).

Table 1. Mean ( \pm 1 s.e.m., 15 mice/group) for first vaginal oestrus in female house mice treated with water or urine from females grouped $8 /$ cage for various lengths of time before being used as urine donors (see text)

\begin{tabular}{lcccccc}
\hline & Exp & Group 1 & Group 2 & Group 3 & Group 4 & Group 5 \\
\hline $\begin{array}{l}\text { Age at first oestrus } \\
\text { (days) }\end{array}$ & I & $33 \cdot 7 \pm 0 \cdot 9^{\mathrm{a}, \mathrm{c}}$ & $32 \cdot 9 \pm 0 \cdot 7^{\mathrm{a}}$ & $33 \cdot 6 \pm 0 \cdot 8^{\mathrm{a}, \mathrm{c}}$ & $36 \cdot 9 \pm 1 \cdot 3^{\mathrm{b}, \mathrm{c}}$ & $38 \cdot 6 \pm 1 \cdot 2^{\mathrm{b}}$ \\
& II & $34 \cdot 5 \pm 0 \cdot 8^{\mathrm{a}}$ & $38 \cdot 3 \pm 1 \cdot 1^{\mathrm{b}, \mathrm{c}}$ & $38 \cdot 1 \pm 1 \cdot 2^{\mathrm{b}, \mathrm{c}}$ & $36 \cdot 0 \pm 1 \cdot 2^{\mathrm{a}, \mathrm{b}}$ & $38 \cdot 6 \pm 0 \cdot 8^{\mathrm{c}}$ \\
\hline
\end{tabular}

Within each row those means not marked by the same superscript are significantly different at $P<0.02$ (Duncan's New Multiple Range Test).

Exp I, $F=5.584 ;$ d.f. $=4,68 ; P<0.01$.

Exp II, $\mathrm{F}=2.967 ;$ d.f. $=4,69 ; P<0.05$. 


\section{Experiments $I I I$ and $I V$}

The duration of daily exposure to the delay chemosignal necessary to produce the delay of sexual maturation in young female mice was investigated.

Methods. Experiment III served as a control for the testing procedure used in Exp. IV. For Exp. III 150 mice were weaned and assigned to 10 treatment groups ( 15 mice/group). All test mice were caged individually. In Group 1 the mice remained in their original cages through the test period. In Group 2 the mice were moved to a clean cage each day. The remaining mice were moved to a clean cage, with fresh bedding, each day for $10 \mathrm{~min}$ (Group 3), $30 \mathrm{~min}$ (Group 4) and for 1, 2, 3, 4, 6 or $12 \mathrm{~h}$ (Groups 5-10, respectively). The shift was initiated between $06: 00$ and $06: 30 \mathrm{~h}$ each day for all treatments. Each test mouse was monitored as described in 'General Methods' until the occurrence of first vaginal oestrus.

The procedure for Exp. IV was similar to that of Exp. III except that mice in Groups 3-10 were transferred each day for the specified length of time to a cage soiled by grouped females. Group 1 females remained in their original cages. Group 2 females were transferred each day to a cage that had previously been inhabited by grouped females. The females used for the soiled cages were adults aged 90-150 days. They were removed from the treatment cages during the daily period of exposure of test females and housed as a unit; they were replaced immediately when the test female was returned to her home cage. To avoid the potential problems associated with these grouped females being absent from their cages for various periods of time, 200 cages of females grouped $8 /$ cage were established for use as treatment cages. The test mice were shifted to different grouped cages each day, according to a random sequence. To prevent the accumulation of wastes in these treatment cages, 50 were changed each day, providing fresh bedding every 4 days; cages changed one day were then used for the subsequent 3 days as treatment cages. Mice were monitored as described in the 'General Methods' until the occurrence of first vaginal oestrus.

Results. There were no significant differences among the 10 treatments in Exp. III (Table 2). Analysis of the data for Exp. IV revealed an overlapping pattern of significant differences (Table 2). Control mice and those in Groups 3 and 4 matured significantly earlier than did mice in Groups 6-10 and 2. Females in Group 5 were intermediate in age at first vaginal oestrus.

Table 2. Mean ( \pm 1 s.e.m., 15 mice/group) for first vaginal oestrus in female house mice treated by shifting the test mouse to a clean cage or a cage soiled by a group of 8 adult females each day for the specified length of time

\begin{tabular}{|c|c|c|c|}
\hline \multirow{2}{*}{\multicolumn{2}{|c|}{ Treatment }} & \multicolumn{2}{|c|}{ Age of first oestrus } \\
\hline & & Clean cage & Soiled cage \\
\hline \multicolumn{2}{|l|}{ Control (remained in same cage throughout) } & $35 \cdot 7 \pm 1 \cdot 0$ & $34 \cdot 1 \pm 0 \cdot 8$ \\
\hline \multicolumn{2}{|l|}{ Shifted $10 \mathrm{~min} /$ day } & $35 \cdot 7 \pm 1 \cdot 1$ & $34 \cdot 3 \pm 1 \cdot 0$ \\
\hline \multicolumn{2}{|l|}{ Shifted $30 \mathrm{~min} /$ day } & $34.9 \pm 1 \cdot 0$ & $35 \cdot 3 \pm 1 \cdot 0$ \\
\hline \multicolumn{2}{|l|}{ Shifted $1 \mathrm{~h} /$ day } & $34 \cdot 3 \pm 0 \cdot 7$ & $37 \cdot 3 \pm 0.8$ \\
\hline \multicolumn{2}{|l|}{ Shifted $2 \mathrm{~h} /$ day } & $34.9 \pm 0 \cdot 7$ & $39 \cdot 1 \pm 0 \cdot 7$ \\
\hline \multicolumn{2}{|l|}{ Shifted $3 \mathrm{~h} /$ day } & $36 \cdot 4 \pm 0.9$ & $38 \cdot 1 \pm 1 \cdot 1$ \\
\hline \multicolumn{2}{|l|}{ Shifted $4 \mathrm{~h} /$ day } & $36 \cdot 1 \pm 0 \cdot 8$ & $38 \cdot 2 \pm 0 \cdot 9$ \\
\hline \multicolumn{2}{|l|}{ Shifted $6 \mathrm{~h} /$ day } & $34 \cdot 8 \pm 1 \cdot 0$ & $38 \cdot 5 \pm 0 \cdot 7$ \\
\hline \multicolumn{2}{|l|}{$\begin{array}{l}\text { Shifted } 12 \mathrm{~h} / \text { day } \\
\text { Shifted once each day }\end{array}$} & $35 \cdot 7 \pm 1 \cdot 1$ & $38 \cdot 7 \pm 0.8$ \\
\hline \multirow[t]{4}{*}{ Shifted once each day } & & $35 \cdot 8 \pm 1 \cdot 0$ & $38 \cdot 9 \pm 1 \cdot 0$ \\
\hline & $F=$ & $0.5 \overline{51}$ & $5 \cdot \overline{467}$ \\
\hline & d.f. $=$ & 9,140 & 9,136 \\
\hline & $P$ & NS & $<0.01$ \\
\hline
\end{tabular}

Those means not connected by the same vertical line are significantly different at $P<0.02$ (Duncan's New Multiple Range Test). 


\section{Discussion}

Two main conclusions are supported by the foregoing experiments. (a) A minimum of about 10 days of grouping at the density used is necessary for females to excrete the maturation-delaying chemosignal in their urine. (2) Young females need at least $2 \mathrm{~h} /$ day of exposure to the chemosignal for the complete delay of puberty.

The bladder urine of singly caged as well as grouped females contains the puberty-delaying chemosignal (McIntosh \& Drickamer, 1977), but mice must be grouped for this substance to occur in an active form in the excreted urine. The results of Exp. I and II indicate that 7-10 days are needed for the physiological processes involved in this transition to occur. That the effect is seemingly a graded process rather than an all-or-none effect is indicated by the fact that mice treated with urine from females grouped for 7-9 days were intermediate in age of puberty in both experiments. By 10-12 days after grouping the delay effect produced by the urine was comparable to that when females had been grouped for long periods of time.

That females need to be grouped for at least 10 days or longer before the delay chemosignal is excreted in their urine makes sense in terms of the evolution of the social and reproductive biology of house mice. Females apparently do not respond to temporary or transitory situations in which they may be exposed to high density or to the urine of females that are at high density by starting to excrete the delay substance in their urine. Drickamer (1982a) has proposed that the urinary chemosignals excreted by females, including the delay substance investigated here and the acceleratory substance(s) in the urine of oestrous females and pregnant or lactating females (Drickamer \& Hoover, 1979), act as signals to other females regarding the adequacy of conditions for reproduction. Females that are themselves reproducing communicate this fact to others by urinary signals, which have probably evolved as epiphenomena. As a modulating influence, the maturation-delaying substance appears in the urine of females in response to an increase in density. This puberty delay signal takes precedence over the acceleratory substances when both are present (Drickamer, 1982b).

Young females must receive several hours per day of exposure to the chemosignal for effective delay of maturation to occur. The mice may carry some of the substance back to their home cage, on their fur or on the feet, but a brief exposure is not sufficient to maintain or set into operation the mechanisms of delay of puberty in young females. Thus a female mouse would not delay an opportunity for commencing reproduction based only on transitory exposure to the delay substance. In addition, as I have previously shown (Drickamer, 1977) at least 4 days and possibly as many as 7 days of urine painting treatment are necessary to produce the delay of first oestrus. It is possible that, with only a brief exposure to the delay chemosignal each day, more days would be needed to achieve the delay of puberty. The question also arises as to whether the effects of exposure to the stimulus are cumulative within a day; i.e. pulsed exposures of the chemosignal might add up to a longer total exposure and thus result in retardation of sexual maturation. Natural selection has probably operated to prevent young female mice from responding too rapidly to the delay chemosignal.

This research was supported by U.S. Public Health Service (NIH) Grant Award No. HD08585 .

\section{References}

Castro, B.M. (1967) Age of puberty in female mice: relationship to population density and the presence of adult males. Anais Acad. bras. Cienc. 39, 289292.

Drickamer, L.C. (1974) Sexual maturation of female house mice: social inhibition. Devl Psychobiol. 7, 257265.
Drickamer, L.C. (1977) Delay of sexual maturation in female house mice by exposure to grouped females or urine from grouped females. J. Reprod. Fert. 51, $77-$ 81.

Drickamer, L.C. (1982a) Delay and acceleration of sexual maturation in female mice by urinary cues from other females. Devl Psychobiol. 15, 433-442. 
Drickamer, L.C. (1982b) Acceleration and delay of sexual maturation in female house mice by urinary cues: dose levels and mixing urine from different sources. Anim. Behav. 30, 456-460.

Drickamer, L.C. \& Hoover, J.E. (1979) Effects of urine from pregnant and lactating female mice on sexual maturation of juvenile females. Devl Psychobiol. 12, 545-551.

Drickamer, L.C. \& McIntosh, T.K. (1980) Effects of adrenalectomy on production and excretion of a pheromone delaying sexual maturation in grouped female mice. Horm. Behav. 14, 146-152.

Drickamer, L.C., McIntosh, T.K. \& Rose, E. (1978) Effects of ovariectomy on production and excretion of a pheromone delaying sexual maturation in female house mice. Horm. Behav. 11, 131-137.

McIntosh, T.K. \& Drickamer, L.C. (1977) Excreted urine, bladder urine and the delay of sexual maturation in female house mice. Anim. Behav. 25, 999 1004.

Rugh, R. (1968) The Mouse: Its Reproduction and Development. Burgess, Minneapolis.

Vandenbergh, J.G. (1969) Male odor acclerates female sexual maturation in mice. Endocrinology 84, 658660.

Vandenbergh, J.G., Drickamer, L.C. \& Colby, D.R. (1972) Social and dietary factors in the sexual maturation of female mice. $J$. Reprod. Fert. 28, 397-405.

Received 10 June 1983 